\title{
Identifying barriers to help-seeking for sexual dysfunction in Multiple Sclerosis
}

Tudor KI ${ }^{1,2}$, Eames $\mathrm{S}^{2}$, Haslam $\mathrm{C}^{2}$, Chataway $\mathrm{J}^{3}$, Liechti $\mathrm{MD}^{2,4}$, Panicker $\mathrm{JN}^{2}$

1 Department of Neurology, University Hospital Centre Zagreb, Zagreb, Croatia

2 Department of Uro-Neurology, The National Hospital for Neurology and Neurosurgery and UCL Institute of Neurology, Queen Square, London, United Kingdom

3 Department of Neuroinflammation, Queen Square Multiple Sclerosis Centre, UCL Institute of Neurology, London, United Kingdom

4 Spinal Cord Injury Center, University of Zurich, Balgrist University Hospital, Zurich, Switzerland

\section{Corresponding author:}

Katarina Ivana Tudor

E-mail address: katarina.ivana.tudor@kbc-zagreb.hr

Mailing address: Department of Neurology, University Hospital Centre Zagreb, Kispaticeva 12, 10000 Zagreb, Croatia Telephone number: $+385(0) 12388340$

\section{Acknowledgements}

The work was undertaken at UCLH/UCL Institute of Neurology and JNP is supported in part by funding from the United Kingdom's Department of Health NIHR Biomedical Research Centres funding scheme.

KIT was awarded funding from International Continence Society (Urodynamics Fellowship), EFNS (Department - Department Cooperation Programme), Guarantors of Brain (Newsom - Davis Visiting Fellowship). MDL was supported by the Swiss National Science Foundatio13n (fellowship P2EZP3_148749 \& P300PB_161087) and the MS society, UK. We would like to acknowledge support of the Multiple Sclerosis Trust of the United Kingdom for carrying out the study and Queen Square MS Centre for useful input during the study.

We would like to thank Martina Doz for statistical support. 


\section{Abstract}

Background: Sexual dysfunction (SD) is common in multiple sclerosis (MS), however under-reported.

Objective: The aim of this study was to identify barriers faced by patients with MS and healthcare professionals (HCPs) in discussing SD.

Methods: This was a two-part prospective study carried out at a tertiary care centre. Patients with MS were surveyed using a 29-item questionnaire and SD was assessed using the MSISQ and ASEX questionnaires; depression screened with PHQ-2. HCPs were surveyed using a 23-item questionnaire.

Results: 74 patients (mean age 42.4 $\pm 10.7,54$ females) and 98 HCPs (mean age 45.8 $\pm 8.9,90$ females) participated. SD was significant, with primary (36.4\%), secondary (27\%) and tertiary (29.8\%) contributory factors. Commonest barriers reported by patients were dominance of neurological symptoms $(\mathrm{N}=30,40.5 \%)$, presence of family or friends $(\mathrm{N}=28$, $37.8 \%)$, and not being asked $(\mathrm{N}=25,33.8 \%)$, while HCPs reported presence of family or friends $(\mathrm{N}=34,34.7 \%)$, lack of knowledge about $\mathrm{SD}(\mathrm{N}=30,30.6 \%)$, and inadequate time during the consultation $(\mathrm{N}=27,27.6 \%)$.

Conclusions: Barriers to discussing SD are similar between patients and HCPs. The most common barriers are addressable through modifications in the clinic environment, raising awareness and providing training opportunities.

Key words: Sexual dysfunction, barriers, healthcare professionals, multiple sclerosis, questionnaires, help-seeking 


\section{Introduction}

Sexual dysfunction (SD) is commonly reported in multiple sclerosis (MS). Reported rates range between 50\% to $90 \%$ in men, and $40 \%$ to $80 \%$ in women [1]. In the multidimensional model of SD, primary (changes in sexual functions due to lesions in nervous system), secondary (caused by neurological disability such as fatigue and spasms, or bladder/bowel incontinence) and tertiary (emotional and psychosocial changes as a result of MS) factors contributing to SD have been identified [2]. SD has been shown to correlate with duration and severity of disease [3], neurological deficits [4], lesion distribution on magnetic resonance imaging (MRI) [5], as well as the presence of brain atrophy, quality of life (QoL) [6] and depression [7]. Treatment strategies exist for managing SD and interventions have been shown to be associated with an improvement in symptoms and QoL [8].

However, screening for SD remains low and SD is often under-diagnosed in clinic [9]. Reasons for this are unclear, however barriers to discussing SD are likely to exist. Studies in chronic medical illnesses have identified different barriers to a discussion including too little time for a discussion, feeling the patient isn't ready, as well as lack of knowledge, awareness, confidence or training amongst healthcare professionals (HCPs) [10] and low level of awareness of later life sexual health issues [11]. Many of these barriers can be addressed. Reluctance of patients in initiating a discussion about SD may arise from a variety of reasons such as a perception that HCPs may not be sufficiently experienced or mature to explore their problems, feelings of shyness and embarrassment, age and gender issues [12].

Patients with neurological disease and their HCPs are likely to be experiencing similar barriers towards discussing SD, however the additional aspect of chronic neurological disabilities and their management is likely to predominate during hospital visits. They are likely to be experiencing symptoms, however these are not being addressed because of nondisclosure. The aim of this study was to identify barriers experienced by patients and HCPs. Recognising these barriers to help-seeking would help to facilitate the discussion of potentially amenable symptoms.

\section{Materials and Methods}

This was a two-part prospective cross-sectional study carried out at a specialist tertiary care teaching hospital over six months. This service evaluation was reviewed and registered with the divisional Quality and Clinical Governance Department. Validated questionnaires evaluating barriers to discussing SD are lacking, and therefore a literature search of studies evaluating barriers faced by patients and HCPs to discussing sexual dysfunction was performed using the search 
engine Pubmed of studies published in the English language till 2013 using the key words "sexual dysfunction", "attitudes", "healthcare professionals", "multiple sclerosis", "quality of life", and "questionnaires".

\section{Part 1 - Survey of patients with MS}

A bespoke 29-item questionnaire included possible barriers that were identified in the literature search [13]. Patients were asked to rate the relevance of the different barriers using a 5-point Likert scale (strongly disagree/ disagree/ neither agree or disagree/ agree/ strongly agree) (Supplementary Material 1). Space was provided for free text to add any additional factors that were perceived as being barriers but not listed in the questionnaire. The Arizona Sexual Experiences Scale (ASEX), a validated 5-item questionnaire which evaluates different domains of SD using a 5-point Likert scale [14], and the Multiple Sclerosis Intimacy and Sexuality Questionnaire (MSISQ), a validated 15-item questionnaire which assesses primary, secondary and tertiary factors that contribute to intimacy and sexual dysfunction specifically in MS using a 5point Likert scale, were also administered [2]. The Patient Health Questionnaire - 2 (PHQ - 2) was included to screen for depressive symptoms using a 4-point Likert scale [15]. Onset of SD and possible sources of help to address the problem, as well as co-morbidities such as lower urinary tract (LUT) and bowel symptoms, cardiovascular disease, gynaecological problems, and medication-use were enquired. The questionnaire was reviewed by five patients with MS attending the outpatient clinic and amended according to the feedback received.

Consecutive patients with MS between the age 16 and 65 who were sexually active, and attending the Uro-Neurology out-patient clinic and Queen-Square Multiple Sclerosis Centre were invited to participate and complete the anonymised questionnaire. Questionnaires were handed in to one of the investigators or returned in the post using pre-stamped envelopes.

Patients reporting a history of a significant psychiatric disorder, MS relapse in the previous 4 weeks, substance abuse, or women either pregnant or having attained the menopause were excluded from the study.

\section{Part 2 - Survey of HCPs}

A bespoke 23-item questionnaire included possible barriers that were identified in the literature search [10,16]. HCPs were asked to rate the relevance of the barriers using a 5-point Likert scale (strongly disagree/ disagree/ neither agree or disagree/ agree/ strongly agree) (Supplementary Material 2). Space was provided for free text to add any additional factors that were perceived as being barriers but not listed in the questionnaire. 
The questionnaire was reviewed by $11 \mathrm{HCPs}$ and amended according to the feedback received. The questionnaire was uploaded onto an online survey portal ( $\underline{\text { SurveyMonkey.com }})$ and was sent by email to 300 HCPs consisting of consultants, nurses, and physiotherapists on the electronic mailing list of the Multiple Sclerosis Trust who are involved in the care of MS patients.

Data was analysed using IBM SPSS Statistics, Version 14 (Armonk, NY: IBM Corp.) for descriptive statistics, and frequency tables. Student's t-test was used to analyse perceived barriers according to gender.

\section{Results}

\section{Part 1 - Survey of patients with MS}

Seventy-four patients with MS $(72.97 \%$ females $(\mathrm{N}=54))$ participated in the study, mean age $42.4 \pm 10.7$ years (range 21 - 64). $70.3 \%(\mathrm{~N}=52)$ had relapsing remitting $\mathrm{MS}, 12.2 \%(\mathrm{~N}=9)$ secondary progressive MS, $10.8 \%(\mathrm{~N}=8)$ primary progressive MS, and 1.4\% ( $=1)$ progressive relapsing MS. Mean duration of disease was $9.8 \pm 8.1$ years. Patients reported the following co-morbidities: lower urinary tract (LUT) symptoms $63.5 \%(\mathrm{~N}=47)$, previous history of surgery $51.4 \%$ $(\mathrm{N}=38)$, bowel problems $43.2 \%(\mathrm{~N}=32)$, high blood pressure $10.8 \%(\mathrm{~N}=8)$, high cholesterol 9.5\% ( $\mathrm{N}=7)$, diabetes mellitus $5.4 \%(\mathrm{~N}=4)$, gynaecological problems $5.4 \%(\mathrm{~N}=4)$ and breast disease $1.4 \%(\mathrm{~N}=1)$.

$16(21.6 \%)$ patients had discussed SD with a HCP and 9 (12.2\%) reported receiving help. The mean ASEX score was 3.4 \pm 0.3 and $24.3 \%(\mathrm{~N}=18$; females: $\mathrm{N}=11$ (20.37\%), males: $\mathrm{N}=7$ (35\%)). According to MSISQ, $36.4 \%(\mathrm{~N}=27)$ reported primary factors, $27 \%(\mathrm{~N}=20)$ secondary, and $29.8 \%(\mathrm{~N}=22)$ tertiary factors contributing to SD (Table 1).

According to the PHQ-2 [15], features of depression were noted in $23.0 \%(\mathrm{~N}=17)$ patients, including little interest or pleasure in doing things $(\mathrm{N}=11,14.86 \%$; females $\mathrm{N}=7$ (12.96\%), males $\mathrm{N}=4(20 \%))$ and feeling down, depressed or hopeless $(\mathrm{N}=15,20.27 \%$, females $\mathrm{N}=9(16.66 \%)$, males $\mathrm{N}=6(30 \%))$. Patients with higher scores on the MSISQ more often reported depressive symptoms on the following domains: muscle tightness or spasms ( $\mathrm{p}=0.023$ ), bowel symptoms $(\mathrm{p}=0.021)$, feeling of being less masculine or feminine due to MS ( $\mathrm{p}=0.027)$, fear of being rejected sexually because of MS ( $\mathrm{p}=0.008)$, worries about the inability to sexually satisfy the partner $(\mathrm{p}=0.002)$ and lack of sexual interest or desire $(\mathrm{p}=0.003)$.

All patients reported at least one barrier and the barriers are listed in order of prevalence in Table 2. Additional barriers listed by patients were uncertainty how the nurse/ doctor would engage in a deeper discussion on bisexuality in a lesbian, gay, bisexual, and transgender (LGBT) relationship $(n=1)$, attaining the menopause $(n=1)$, perception that sexual problems were not issues discussed beyond a certain age $(n=1)$, perception that doctors were embarrassed or unsure about 
discussing sexual problems $(n=1)$, impact of sexual dysfunction on the spouse $(n=1)$ and the impact of fatigue on sexual performance $(n=1)$.

Patients preferred the following sources for seeking help: consultants $(\mathrm{N}=43,58.1 \%)$, nurses $(\mathrm{N}=39,52.7 \%), \mathrm{GPs}(\mathrm{N}=38$, $51.4 \%)$, MS charities $(\mathrm{N}=28,37.8 \%)$, another person with $\mathrm{MS}(\mathrm{N}=20,27 \%)$, physiotherapist $(\mathrm{N}=18,24.3 \%)$, junior doctor $(\mathrm{N}=10,13.5 \%)$, the internet $(\mathrm{N}=10,13.5 \%)$, friends or relatives $(\mathrm{N}=10,13.5 \%)$.

\section{Part 2- Survey of HCPs}

98 HCPs participated in the survey $(91.8 \%(\mathrm{~N}=90)$ females, mean age $45.8 \pm 8.9$ years $)$ and comprised of nurses $(\mathrm{N}=82$, 83.7\%), consultants $(\mathrm{N}=7,7.1 \%)$, therapists $(\mathrm{N}=4,4.1 \%)$ and others $(\mathrm{N}=4,4.1 \%)$. Mean duration since primary qualification was $23.3 \pm 9.6$ years.

All HCPs reported at least one barrier and these are listed in order of prevalence in Table 3 . There were no significant differences in perceived barriers between male and female HCPs.

HCPs with more years of experience reported more confidence, awareness and knowledge when dealing with sexual issues. Their perception of the prevalence of sexual problems increases with years of experience, and they are more likely to initiate the conversation, discuss and follow a structured approach (Supplementary Material 3).

Barriers perceived by patients were compared with barriers perceived by HCPs (Tables 2 and 3 ) and proposals to address the same are provided (Table 4).

Most barriers were reported with similar prevalence. Barriers that were significantly more reported by patients were the perception of being pointless to raise $\mathrm{SD}$ as there was no treatment $(\mathrm{p}=0.000)$, age gap between patient and $\mathrm{HCP}(\mathrm{p}=0.000)$ and perception that SD is not an MS-related problem ( $\mathrm{p}=0.000)$. Barriers that were significantly more reported by HCPs were presence of family or friends in the consultation room $(\mathrm{p}=0.043)$, fear of appearing to be inappropriate $(\mathrm{p}=0.001)$ and fear of offending $(\mathrm{p}=0.000)$.

\section{Discussion}

The study aimed to evaluate perceived barriers to discussing sexual problems in an unselected take of patients affected by MS and HCPs involved in the care of patients. Through identifying barriers we hope to help address this potentially solvable issue [17]. Different dimensions of SD were explored and primary factors were found to be contributing to SD most commonly, followed by tertiary and secondary factors. Depressive symptoms were present in a substantial number of patients, and was associated with greater degree of SD, as well as with the presence of tertiary factors contributing to SD, followed by secondary and primary factors. Despite the high prevalence of SD reported in MS, SD was addressed 
in only a small number of patients at this tertiary-level teaching hospital, and was smaller than from previous studies elsewhere [13].

A few studies have evaluated barriers to discussing SD in different populations of HCPs and patients, and include the perception of general practitioners when seeing patients with cardiac disease, in cardiology practice $[10,16]$, in the primary care setting [18], amongst patients with MS [13], amongst neurosurgical doctors when seeing patients with spinal disease [19], patients with type 2 diabetes patients [20], patients with cancer [21,22], oncology nurses [23], and amongst patients with low back pain [24]. Possible barriers were selected following a review of these studies, and very few participants indicated additional barriers in the free text box, suggesting that barriers experienced are similar across different diseases. All patients and HCPs in the study recognised at least one barrier to discussing SD. Most barriers were reported with similar prevalence, and the order of prevalence was similar between the two groups. Several barriers were identified, however none were reported in more than $50 \%$ of the respective group. One of the commonest barriers reported by patients was not being asked about sexual problems. It has been previously demonstrated that bladder and bowel symptoms were being ignored by medical staff [25], and the results of this study suggests this extends to sexual dysfunction as well.

The presence of family or friends in the consultation room was frequently cited both by HCPs ( $\mathrm{n}=34,34.7 \%)$ and patients $(\mathrm{N}=28,37.8 \%)$ as a barrier. The need for privacy is an important consideration when discussing this intimate problem, and is a consistent finding in different studies [26,27]. Often a carer, friend or relative accompanies the patient which makes the topic difficult to address. Presence of family and friends was a barrier reported by women and men, however in a sizeable number $(\mathrm{N}=17,23 \%)$ presence of another $\mathrm{HCP}$ in the room was also a barrier, indicative of the intimate nature of the conversation.

The limited time available in a consultation results in a prioritisation of symptoms for discussion. Previous studies have demonstrated that assessment of pelvic organ complaints are limited by time constraints and staff workloads, since clinic visits can be lengthy and pelvic organ complaints are not necessarily the primary aim of the visit [25]. 29.7\% of the patients indicated that addressing sexual difficulties was a priority and therefore it would be appropriate to incorporate within the consultation a period of time without accompanying carers, partners or friends, where intimate matters could be addressed. Possibly using symptom check-lists filled in before the appointment so that HCPs are aware about the different symptoms that need to be discussed could help address this issue. Alternatively, the conversation may need to be staggered over several consultations to accommodate time to discuss this intimate topic, or joining up a doctor-led and nurse-led clinics so that sufficient time is available. 
Patients perceived that SD is not an MS-related problem and perceived age gap as a barrier compared to HCPs. HCPs should be aware of this and should strive to initiate the conversation whenever possible. Initiating the conversation on $\mathrm{SD}$ is beset with uncertainty however, not being asked was a barrier reported by $33.8 \%(\mathrm{~N}=25)$ of patients. For a sizeable number, patient is expecting that the HCP should be initiating the discussion. Only $6 \%$ of patients have ever discussed their concerns with a medical professional or undergone sexual therapy [28]. Introducing the topic involves giving permission to the patient to bring up the topic through open-ended questions. The PLISSIT (permission, limited information, specific suggestions and intensive therapy) model which facilitates a structured approach to addressing SD has been advocated as a framework to help HCPs address the problem of sexual dysfunction [29]. As the initial step, giving permission to the patient to discuss SD in itself is quite helpful for both patient and HCP to help initiate the discussion, and to then take this further according to the requirements of the patient [29]. Being a sensitive matter, the discussion could be initiated around bladder and bowel complaints as a way of entry, to then bring up a discussion thereafter about more intimate problems such as sexual difficulties [30].

More often women rather than men felt a discussion about SD was pointless. This reflects the current availability of treatment options regarding management of SD which are much more established in men than women [31,32]. However, options for managing sexual dysfunction in women do exist and women should be aware where such information can be accessed. Greater awareness amongst patients that SD can occur as a result of MS or its related disability would help considerably to dispel notions and myths about SD, but also to help patients become more confident about addressing the topic. Patient information days and leaflets available through reputable organisations such as MS charities are an important resource for patients to utilise.

In clinical practice, poor communication with the $\mathrm{HCP}$ has been highlighted as a significant barrier to seeking help for SD. Absence of knowledge, confidence and comfort was previously reported in HCPs as barriers to the discussion about sexual functions [21]. 55\% of males and 39\% of female patients with MS were able to discuss their sexual difficulties with their health care professionals (HCPs) and low satisfaction rates were reported [13]. Lack of knowledge was cited by more than $30 \%$ of HCPs and could be addressed by improving knowledge and training in the evaluation and management of SD through study days and short spells of observer-ships in specialist units, training sessions in communication, and providing opportunities for further exposure in addressing sexual dysfunction and providing a framework for discussion according to the PLISSIT model [33,34]. HCPs with more years of experience seem more skilled in addressing SD, however due to small sample size and lack of statistical power further statistical analysis could not be performed. 
Contrary to our expectations, only a small number of patients and HCPs reported language, religious, or cultural factors and gender as barriers to a discussion. The survey did not capture information about cultural and religious factors that could influence a discussion on SD [35], however the study was carried out at a centre that caters to a large multi-ethnic population. This would need to be evaluated in further studies.

The absence of a validated questionnaire to evaluate barriers necessitated designing a questionnaire based on the known barriers from the literature. The questionnaires were however reviewed by patients and HCPs, respectively, before use. Nevertheless, these results from a sizeable number of patients and HCPs provide preliminary information about possible barriers. The questionnaires should be validated so that a standardised assessment is possible across different centres and different neurological conditions. The validated questionnaire would serve to enhance awareness of the problems identified in this study. Future studies should be designed to explore in-depth these barriers to help-seeking perceived by patients and HCPs. Thematic based interviews in the framework of a qualitative study would allow a comprehensive assessment of ways to address these different barriers. The results may not be generalisable across different societies as the perception of barriers is likely to by culturally influenced. Future studies should explore similarities and differences in perceived barriers across different populations.

In conclusion, several barriers to help-seeking for SD were identified, and these contribute to the under-reporting of this significant problem. Modifications in the clinic environment, raising awareness about SD amongst patients and providing training opportunities for HCPs will help address these different barriers, and thereby help narrow the treatment gap for this potentially amenable problem. 
This prospective service evaluation was approved and registered with the Queen Square Division Quality and Clinical Governance Department.

On behalf of all authors, the corresponding author states that there is no conflict of interest. 


\section{References}

1. Kessler TM, Fowler CJ, Panicker JN (2009) Sexual dysfunction in multiple sclerosis. Expert Rev Neurother 9 (3):341-350. doi:10.1586/14737175.9.3.341

2. Foley FW, Zemon V, Campagnolo D, Marrie RA, Cutter G, Tyry T, Beier M, Farrell E, Vollmer T, Schairer L (2013) The Multiple Sclerosis Intimacy and Sexuality Questionnaire -- re-validation and development of a 15-item version with a large US sample. Mult Scler 19 (9):1197-1203. doi:10.1177/1352458512471876

3. Mohammadi K, Rahnama P, Moayed Mohseni S, Sahraian MA, Montazeri A (2013) Determinants of sexual dysfunction in women with multiple sclerosis. BMC neurology 13 (1):83. doi:10.1186/1471-2377-13-83

4. Kurtzke JF (1983) Rating neurologic impairment in multiple sclerosis: an expanded disability status scale (EDSS). Neurology 33 (11):1444-1452

5. Winder K, Linker RA, Seifert F, Deutsch M, Engelhorn T, Dorfler A, Lee DH, Hosl KM, Hilz MJ (2016) Neuroanatomic Correlates of Female Sexual Dysfunction in Multiple Sclerosis. Ann Neurol 80 (4):490-498. doi:10.1002/ana.24746

6. Janardhan V, Bakshi R (2000) Quality of life and its relationship to brain lesions and atrophy on magnetic resonance images in 60 patients with multiple sclerosis. Archives of neurology 57 (10): 1485-1491

7. Forbes A, While A, Mathes L, Griffiths P (2006) Health problems and health-related quality of life in people with multiple sclerosis. Clinical rehabilitation 20 (1):67-78

8. Lombardi G, Musco S, Kessler TM, Li Marzi V, Lanciotti M, Del Popolo G (2015) Management of sexual dysfunction due to central nervous system disorders: a systematic review. BJU Int 115 Suppl 6:47-56. doi:10.1111/bju.13055

9. Guo ZN, He SY, Zhang HL, Wu J, Yang Y (2012) Multiple sclerosis and sexual dysfunction. Asian J Androl 14 (4):530-535. doi:10.1038/aja.2011.110

10. Byrne M, Doherty S, McGee HM, Murphy AW (2010) General practitioner views about discussing sexual issues with patients with coronary heart disease: a national survey in Ireland. BMC family practice 11:40. doi:10.1186/1471-2296-11-40

11. Gott M, Hinchliff S, Galena E (2004) General practitioner attitudes to discussing sexual health issues with older people. Soc Sci Med 58 (11):2093-2103. doi:10.1016/j.socscimed.2003.08.025 12. Albarran JW, Bridger S (1997) Problems with providing education on resuming sexual activity after myocardial infarction: developing written information for patients. Intensive Crit Care Nurs 13 (1):2-11

13. Redelman MJ (2009) Sexual difficulties for persons with multiple sclerosis in New South Wales, Australia. Int J Rehabil Res 32 (4):337-347. doi:10.1097/MRR.0b013e3283298166 14. McGahuey CA, Gelenberg AJ, Laukes CA, Moreno FA, Delgado PL, McKnight KM, Manber R (2000) The Arizona Sexual Experience Scale (ASEX): reliability and validity. J Sex Marital Ther $26(1): 25-40$

15. Kroenke K, Spitzer RL, Williams JB (2003) The Patient Health Questionnaire-2: validity of a two-item depression screener. Medical care 41 (11):1284-1292.

doi:10.1097/01.MLR.0000093487.78664.3C

16. Nicolai MP, Both S, Liem SS, Pelger RC, Putter H, Schalij MJ, Elzevier HW (2013) Discussing sexual function in the cardiology practice. Clin Res Cardiol 102 (5):329-336. doi:10.1007/s00392-

013-0549-2 
17. Foley FW, LaRocca NG, Sanders AS, Zemon V (2001) Rehabilitation of intimacy and sexual dysfunction in couples with multiple sclerosis. Mult Scler 7 (6):417-421

18. Tong SF, Low WY, Ismail SB, Trevena L, Wilcock S (2013) Determinants of doctors' decisions to inquire about sexual dysfunction in Malaysian primary care settings. Transl Androl Urol 2

(4):281-290. doi:10.3978/j.issn.2223-4683.2013.09.14

19. Korse NS, Nicolai MP, Both S, Vleggeert-Lankamp CL, Elzevier HW (2016) Discussing sexual health in spinal care. Eur Spine J 25 (3):766-773. doi:10.1007/s00586-015-3991-1

20. Rutte A, Welschen LM, van Splunter MM, Schalkwijk AA, de Vries L, Snoek FJ, Enzlin P, Nijpels G, Elders PJ (2016) Type 2 Diabetes Patients' Needs and Preferences for Care Concerning Sexual Problems: A Cross-Sectional Survey and Qualitative Interviews. J Sex Marital Ther 42 (4):324-337. doi:10.1080/0092623X.2015.1033578

21. Ussher JM, Perz J, Gilbert E, Wong WK, Mason C, Hobbs K, Kirsten L (2013) Talking about sex after cancer: a discourse analytic study of health care professional accounts of sexual communication with patients. Psychol Health 28 (12):1370-1390. doi:10.1080/08870446.2013.811242

22. Traa MJ, De Vries J, Roukema JA, Rutten HJ, Den Oudsten BL (2014) The sexual health care needs after colorectal cancer: the view of patients, partners, and health care professionals. Support Care Cancer 22 (3):763-772. doi:10.1007/s00520-013-2032-z

23. Krouwel EM, Nicolai MP, van Steijn-van Tol AQ, Putter H, Osanto S, Pelger RC, Elzevier HW (2015) Addressing changed sexual functioning in cancer patients: A cross-sectional survey among Dutch oncology nurses. Eur J Oncol Nurs 19 (6):707-715. doi:10.1016/j.ejon.2015.05.005

24. Bahouq H, Allali F, Rkain H, Hajjaj-Hassouni N (2013) Discussing sexual concerns with chronic low back pain patients: barriers and patients' expectations. Clin Rheumatol 32 (10):14871492. doi:10.1007/s10067-013-2299-y

25. Brucker BM, Nitti VW, Kalra S, Herbert J, Sadiq A, Utomo P, Aponte MM (2017) Barriers experienced by patients with multiple sclerosis in seeking care for lower urinary tract symptoms. Neurourol Urodyn 36 (4):1208-1213. doi:10.1002/nau.23101

26. Villar F, Celdran M, Faba J, Serrat R (2014) Barriers to sexual expression in residential aged care facilities (RACFs): comparison of staff and residents' views. J Adv Nurs 70 (11):2518-2527. doi:10.1111/jan.12398

27. Fuzzell L, Fedesco HN, Alexander SC, Fortenberry JD, Shields CG (2016) "I just think that doctors need to ask more questions": Sexual minority and majority adolescents' experiences talking about sexuality with healthcare providers. Patient Educ Couns 99 (9):1467-1472.

doi:10.1016/j.pec.2016.06.004

28. Lew-Starowicz M, Rola R (2014) Sexual dysfunctions and sexual quality of life in men with multiple sclerosis. J Sex Med 11 (5):1294-1301. doi:10.1111/jsm.12474

29. Annon JS (1976) The PLISSIT model: a proposed conceptual scheme for the behavioral treatment of sexual problems. J Sex Ed \& Ther 2 (2):1 - 15

30. Panicker JN, Fowler CJ, Kessler TM (2015) Lower urinary tract dysfunction in the neurological patient: clinical assessment and management. Lancet Neurol 14 (7):720-732. doi:10.1016/S14744422(15)00070-8

31. Wespes E, Amar E, Hatzichristou D, Hatzimouratidis K, Montorsi F, Pryor J, Vardi Y, Eau (2006) EAU Guidelines on erectile dysfunction: an update. Eur Urol 49 (5):806-815.

doi:10.1016/j.eururo.2006.01.028

32. Hatzimouratidis K, Salonia A, Adaikan G, Buvat J, Carrier S, El-Meliegy A, McCullough A, Torres LO, Khera M (2016) Pharmacotherapy for Erectile Dysfunction: Recommendations From the Fourth International Consultation for Sexual Medicine (ICSM 2015). The journal of sexual medicine 13 (4):465-488. doi:10.1016/j.jsxm.2016.01.016

33. Tsimtsiou Z, Hatzimouratidis K, Nakopoulou E, Kyrana E, Salpigidis G, Hatzichristou D (2006) Predictors of physicians' involvement in addressing sexual health issues. J Sex Med 3 (4):583-588. doi:10.1111/j.1743-6109.2006.00271.x

34. Foley S, Wittmann D, Balon R (2010) A multidisciplinary approach to sexual dysfunction in medical education. Acad Psychiatry 34 (5):386-389. doi:10.1176/appi.ap.34.5.386 
35. Lai PS, Tan SY, Liew SM (2016) Views and Experiences of Malaysian Family Medicine Trainees of Female Sexual Dysfunction. Arch Sex Behav 45 (8):2081-2089. doi:10.1007/s10508-0160796-1 
Table 1. Contributory factors to SD and their prevalence according to the MSISQ

\begin{tabular}{|c|c|c|c|}
\hline Primary & Total N(\%) & Females N(\%) & Males N(\%) \\
\hline $\begin{array}{l}\text { Lack of sexual interest or } \\
\text { desire }\end{array}$ & $24(32.5)$ & 19 (35.18) & $5(25)$ \\
\hline $\begin{array}{l}\text { Takes too long to orgasm } \\
\text { or climax }\end{array}$ & $23(31.1)$ & $18(33.33)$ & $5(25)$ \\
\hline $\begin{array}{l}\text { Less feeling or numbness } \\
\text { in my genitals }\end{array}$ & $21(28.4)$ & $16(29.62)$ & $5(25)$ \\
\hline $\begin{array}{l}\text { Less intense or pleasura- } \\
\text { ble orgasms or climaxes }\end{array}$ & $18(24.4)$ & $12(22.22)$ & $6(30)$ \\
\hline $\begin{array}{l}\text { Men reported difficulty } \\
\text { in getting or keeping a } \\
\text { satisfactory erection }\end{array}$ & 14 (18.9) & NA & $14(70)$ \\
\hline $\begin{array}{l}\text { Women reported inade- } \\
\text { quate lubrication or wet- } \\
\text { ness }\end{array}$ & 13 (17.6) & $13(24)$ & NA \\
\hline \multicolumn{4}{|l|}{ Secondary } \\
\hline $\begin{array}{l}\text { Bladder or urinary symp- } \\
\text { toms }\end{array}$ & $20(27)$ & $16(29.62)$ & $4(20)$ \\
\hline $\begin{array}{l}\text { Muscle tightness or } \\
\text { spasms in arms, legs or } \\
\text { body }\end{array}$ & $15(20.3)$ & $11(20.37)$ & $4(20)$ \\
\hline $\begin{array}{l}\text { Pain, burning or discom- } \\
\text { fort in body }\end{array}$ & $10(13.5)$ & $8(14.81)$ & $2(10)$ \\
\hline Bowel symptoms & $7(9.5)$ & $6(11.11)$ & $1(5)$ \\
\hline $\begin{array}{l}\text { Tremors or shaking in } \\
\text { hands or body }\end{array}$ & $7(9.5)$ & $3(5.55)$ & $4(20)$ \\
\hline \multicolumn{4}{|l|}{ Tertiary } \\
\hline $\begin{array}{l}\text { Feeling less confident } \\
\text { about my sexuality due } \\
\text { to MS }\end{array}$ & $22(29.8)$ & $14(25.92)$ & $8(40)$ \\
\hline $\begin{array}{l}\text { Worries about sexually } \\
\text { satisfying my partner }\end{array}$ & $17(23)$ & $11(20.37)$ & $6(30)$ \\
\hline $\begin{array}{l}\text { Feeling less masculine or } \\
\text { feminine due to MS }\end{array}$ & $16(21.6)$ & $13(24.07)$ & $3(15)$ \\
\hline $\begin{array}{l}\text { Feeling their body is less } \\
\text { attractive }\end{array}$ & $15(20.3)$ & $12(22.22)$ & $3(15)$ \\
\hline
\end{tabular}




\begin{tabular}{|l|l|l|l|}
\hline $\begin{array}{l}\text { Fear of being rejected } \\
\text { sexually because of MS }\end{array}$ & $14(19)$ & $10(18.51)$ & $4(20)$ \\
\hline
\end{tabular}

SD: sexual dysfunction, MSISQ: Multiple Sclerosis Intimacy and Sexuality Questionnaire, MS: multiple sclerosis, NA: not applicable

Figures represent numbers scoring highly likely and likely on the Likert scale 
Table 2. Barriers perceived by MS patients, listed in order of prevalence

\begin{tabular}{|c|c|c|c|}
\hline Barriers (Agree/ Strongly agree) & $\begin{array}{l}\text { Total } \\
(\mathbf{N}=74) \\
\mathrm{N}(\%)\end{array}$ & $\begin{array}{l}\text { Female } \\
(\mathrm{N}=54) \\
\mathrm{N}(\%)\end{array}$ & $\begin{array}{l}\text { Male } \\
(\mathbf{N}=20) \\
\mathbf{N}(\%)\end{array}$ \\
\hline Other MS symptoms overshadow sexual problems & $30(40.5)$ & $24(44.44)$ & $6(30)$ \\
\hline Presence of family or friends in the consultation room & $28(37.8)$ & $19(35.18)$ & $9(45)$ \\
\hline The doctor/ nurse not asking about sexual problems & $25(33.8)$ & $21(38.88)$ & $4(20)$ \\
\hline Sexual problems are low priority & $24(32.5)$ & $20(37.03)$ & $4(20)$ \\
\hline Lack of time to discuss during the consultation & $21(28.4)$ & $16(29.62)$ & $5(25)$ \\
\hline Feeling that it's pointless to ask because there's no treatment & $20(27.1)$ & $17(31.48)$ & $3(15)$ \\
\hline Lack of rapport with the doctor/ nurse & $18(24.3)$ & $15(27.77)$ & $3(15)$ \\
\hline Anxiety and discomfort about discussing sexual problems & $17(23)$ & $13(24.07)$ & $4(20)$ \\
\hline Presence of other doctors/ nurses in the consultation room & $17(23)$ & $13(24.07)$ & $4(20)$ \\
\hline Feeling shy or embarrassed about discussing sexual problems & $17(23)$ & $14(25.92)$ & $3(15)$ \\
\hline Doctor /nurse being of the opposite gender & $16(21.6)$ & $14(25.92)$ & $2(10)$ \\
\hline Own attitudes and beliefs towards sexual problems & $13(17.6)$ & $10(18.51)$ & $3(15)$ \\
\hline Currently not being in a relationship & $13(17.6)$ & $7(12.96)$ & $6(30)$ \\
\hline Concern that a discussion on sexual problems might reveal something embarrassing & $11(14.9)$ & $8(14.81)$ & $3(15)$ \\
\hline Fear of appearing to be inappropriate & $10(13.6)$ & $9(16.66)$ & $1(5)$ \\
\hline Fear of offending the doctor/nurse & $10(13.5)$ & $9(16.66)$ & $1(5)$ \\
\hline Perceived age gap with the doctor/nurse & $7(9.5)$ & $6(11.11)$ & $1(5)$ \\
\hline Discussion interferes with privacy & $7(9.5)$ & $4(7.4)$ & $3(15)$ \\
\hline Perception that sexual dysfunction is not an MS-related problem & $6(8.1)$ & $5(9.25)$ & $1(5)$ \\
\hline Language barriers & $3(4.1)$ & $3(5.55)$ & $0(0)$ \\
\hline Religious or cultural factors & $2(2.7)$ & $2(3.7)$ & $0(0)$ \\
\hline
\end{tabular}

MS: multiple sclerosis 
Table 3. Barriers perceived by HCPs, listed in order of prevalence

\begin{tabular}{|c|c|c|c|}
\hline Barriers (Agree/ Strongly agree) & $\begin{array}{l}\text { Total } \\
(\mathbf{N}=98(\mathbf{N})) \\
\mathbf{N}(\%)\end{array}$ & $\begin{array}{l}\text { Female } \\
\text { (90 female) } \\
\mathbf{N}(\%)\end{array}$ & $\begin{array}{l}\text { Male } \\
(8 \text { male }) \\
N(\%)\end{array}$ \\
\hline Presence of family or friends in the consultation room & $34(34.7)$ & $30(33.70)$ & $4(50)$ \\
\hline Lack of knowledge in this field & $30(30.6)$ & $28(31.46)$ & $2(25)$ \\
\hline Lack of time to discuss during the consultation & $27(27.6)$ & $25(28.08)$ & $2(25)$ \\
\hline Perception that patient is not ready to discuss sexual problem & $27(27.6)$ & $24(26.96)$ & $3(37.5)$ \\
\hline Concern that discussing sexual problems may increase patient's anxiety and discomfort & $23(23.4)$ & $19(21.34)$ & $4(50)$ \\
\hline Other MS related symptoms overshadow sexual problems & $22(22.5)$ & $19(21.34)$ & $3(37.5)$ \\
\hline Lack of rapport with the patient & $20(20.4)$ & $18(20.22)$ & $2(25)$ \\
\hline Fear of offending the patient & $20(20.4)$ & $18(20.22)$ & $2(25)$ \\
\hline Not adequately trained to discuss sexual problems & $19(19.4)$ & $18(20.22)$ & $1(12.5)$ \\
\hline Fear of appearing to be inappropriate & $17(17.3)$ & $14(15.73)$ & $3(37.5)$ \\
\hline Patient not asking about sexual problems & $16(16.4)$ & $14(15.73)$ & $2(25)$ \\
\hline Elderly age of the patient & $14(14.3)$ & $12(13.48)$ & $2(25)$ \\
\hline Presence of other doctors/nurses in the consultation room & $11(11.2)$ & $9(10.11)$ & $2(25)$ \\
\hline I feel shy or embarrassed about discussing sexual problems & $10(10.2)$ & $8(8.98)$ & $2(25)$ \\
\hline Patient being of the opposite gender & $8(8.2)$ & $5(5.61)$ & $3(37.5)$ \\
\hline Language barriers & $8(8.2)$ & $7(7.86)$ & $1(12.5)$ \\
\hline Own attitudes and beliefs towards sexual problems & $7(7.1)$ & $7(7.86)$ & $0(0)$ \\
\hline Perceived age gap with the patient & $5(5.1)$ & $3(3.37)$ & $2(25)$ \\
\hline Perception that discussing sexual problems is someone else's responsibility & $4(4.1)$ & $4(4.49)$ & $0(0)$ \\
\hline Feeling that it's pointless to ask because there's no treatment & $2(2)$ & $1(1.12)$ & $1(12.5)$ \\
\hline Religious or cultural factors & $2(2)$ & $2(2.24)$ & $0(0)$ \\
\hline Perception that sexual dysfunction is not an MS-related problem & 0 & $0(0)$ & $0(0)$ \\
\hline
\end{tabular}

HCPs: Healthcare professionals 
Table 4. Barriers faced by MS patients and HCPs with proposed solutions

\begin{tabular}{|c|c|c|c|c|c|c|c|c|c|c|}
\hline \multicolumn{4}{|c|}{ Patients with MS } & \multicolumn{4}{|c|}{ HCPs } & \multirow[t]{2}{*}{ p-value } & \multicolumn{2}{|c|}{ Proposals to address barriers } \\
\hline $\begin{array}{l}\text { Barriers (Agree/ } \\
\text { Strongly agree) }\end{array}$ & $\begin{array}{l}\text { Total } \\
(\mathrm{N}=74) \\
\mathrm{N}(\%)\end{array}$ & $\begin{array}{l}\text { Female } \\
(\mathrm{N}=54 \\
(73 \%)) \\
\mathrm{N}(\%)\end{array}$ & $\begin{array}{l}\text { Male } \\
(\mathrm{N}=20 \\
(27 \%)) \\
\mathrm{N}(\%)\end{array}$ & $\begin{array}{c}\text { Barriers } \\
\text { (Agree/ } \\
\text { Strongly } \\
\text { agree) }\end{array}$ & $\begin{array}{l}\text { Total } \\
(\mathrm{N}=98 \\
(\mathrm{N})) \\
\mathrm{N}(\%)\end{array}$ & $\begin{array}{l}\text { Female } \\
(90 \\
\text { female } \\
(91.83 \\
\%) \\
\mathrm{N}(\%)\end{array}$ & $\begin{array}{l}\text { Male } \\
(8 \text { male } \\
(8.2 \%)) \\
N(\%)\end{array}$ & & & \\
\hline $\begin{array}{l}\text { My other MS } \\
\text { symptoms } \\
\text { overshadow sexual } \\
\text { problems }\end{array}$ & $\begin{array}{c}30 \\
(40.5)\end{array}$ & $\begin{array}{c}24 \\
(44.44)\end{array}$ & $6(30)$ & $\begin{array}{l}\text { The patient's } \\
\text { other MS } \\
\text { related } \\
\text { symptoms } \\
\text { overshadow } \\
\text { sexual } \\
\text { problems }\end{array}$ & $\begin{array}{c}22 \\
(22.5)\end{array}$ & $\begin{array}{c}19 \\
(21.34)\end{array}$ & $3(37.5)$ & 0.097 & $\square$ & $\begin{array}{l}\text { Explaining the } \\
\text { association } \\
\text { between MS and } \\
\text { SD and giving } \\
\text { permission to } \\
\text { patients to discuss } \\
\text { SD during clinic } \\
\text { visits }\end{array}$ \\
\hline $\begin{array}{l}\text { Presence of family } \\
\text { or friends in the } \\
\text { consultation room }\end{array}$ & $\begin{array}{c}28 \\
(37.8)\end{array}$ & $\begin{array}{c}19 \\
(35.18)\end{array}$ & $9(45)$ & $\begin{array}{l}\text { Presence of } \\
\text { family or } \\
\text { friends in the } \\
\text { consultation } \\
\text { room }\end{array}$ & $\begin{array}{c}34 \\
(34.7)\end{array}$ & $\begin{array}{c}30 \\
(33.70)\end{array}$ & $4(50)$ & 0.043 & $\square$ & $\begin{array}{l}\text { Set aside a part of } \\
\text { the consultation } \\
\text { with the patient } \\
\text { alone }\end{array}$ \\
\hline $\begin{array}{l}\text { The doctor/ nurse } \\
\text { not asking about } \\
\text { the problem }\end{array}$ & $\begin{array}{c}25 \\
(33.8)\end{array}$ & $\begin{array}{c}21 \\
(38.88)\end{array}$ & $4(20)$ & $\begin{array}{l}\text { Patient does } \\
\text { not ask about } \\
\text { the problem }\end{array}$ & $\begin{array}{c}16 \\
(16.4)\end{array}$ & $\begin{array}{c}14 \\
(15.73)\end{array}$ & $2(25)$ & 0.100 & 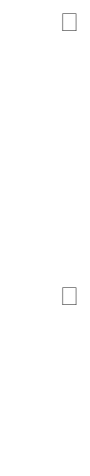 & $\begin{array}{l}\text { Educating HCPs } \\
\text { about giving } \\
\text { permission to } \\
\text { patients to discuss } \\
\text { SD in the } \\
\text { framework of the } \\
\text { PLISSIT model } \\
\text { MS information } \\
\text { leaflets } \\
\text { encouraging } \\
\text { patients to raise } \\
\text { the topic of SD } \\
\text { during clinic visits }\end{array}$ \\
\hline $\begin{array}{l}\text { Sexual problems } \\
\text { are low in my } \\
\text { priorities }\end{array}$ & $\begin{array}{c}24 \\
(32.5)\end{array}$ & $\begin{array}{c}20 \\
(37.03)\end{array}$ & $4(20)$ & & & & & & 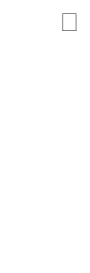 & $\begin{array}{l}\text { Explaining the } \\
\text { association } \\
\text { between MS and } \\
\text { SD and giving } \\
\text { permission to } \\
\text { patients to discuss } \\
\text { SD during clinic } \\
\text { visits if relevant }\end{array}$ \\
\hline Lack of time & $\begin{array}{c}21 \\
(28.4)\end{array}$ & $\begin{array}{c}16 \\
(29.62)\end{array}$ & $5(25)$ & Lack of time & $\begin{array}{c}27 \\
(27.6)\end{array}$ & $\begin{array}{c}25 \\
(28.08)\end{array}$ & $2(25)$ & 0.266 & $\square$ & $\begin{array}{l}\text { Use of symptom } \\
\text { check-lists to } \\
\text { identify priority } \\
\text { areas for review } \\
\text { during the clinic } \\
\text { visit } \\
\text { Staggering the } \\
\text { discussion over } \\
\text { several } \\
\text { consultations to } \\
\text { allow for time } \\
\text { time to discuss this } \\
\text { intimate topic } \\
\text { Joining up doctor- } \\
\text { led and nurse-led } \\
\text { clinics so that } \\
\text { sufficient time is } \\
\text { available }\end{array}$ \\
\hline
\end{tabular}




\begin{tabular}{|c|c|c|c|c|c|c|c|c|c|c|}
\hline $\begin{array}{l}\text { Feeling that it's } \\
\text { pointless to ask } \\
\text { because there's no } \\
\text { treatment }\end{array}$ & $\begin{array}{c}20 \\
(27.1)\end{array}$ & $\begin{array}{c}17 \\
(31.48)\end{array}$ & $3(15)$ & $\begin{array}{l}\text { No point in } \\
\text { asking } \\
\text { because } \\
\text { there's no } \\
\text { treatment }\end{array}$ & $2(2)$ & $\begin{array}{c}1 \\
(1.12)\end{array}$ & $1(12.5)$ & 0.000 & $\square$ & $\begin{array}{l}\text { Explaining the } \\
\text { association } \\
\text { between MS and } \\
\text { SD and the } \\
\text { different } \\
\text { therapeutic } \\
\text { strategies for } \\
\text { managing sexual } \\
\text { difficulties } \\
\text { MS information } \\
\text { leaflets } \\
\text { highlighting } \\
\text { treatment options } \\
\text { for managing SD }\end{array}$ \\
\hline $\begin{array}{l}\text { Lack of rapport } \\
\text { with doctor/ nurse }\end{array}$ & $\begin{array}{c}18 \\
(24.3)\end{array}$ & $\begin{array}{c}15 \\
(27.77)\end{array}$ & $3(15)$ & $\begin{array}{l}\text { Lack of } \\
\text { rapport with } \\
\text { the patient }\end{array}$ & $\begin{array}{c}20 \\
(20.4)\end{array}$ & $\begin{array}{c}18 \\
(20.22)\end{array}$ & $2(25)$ & 0.408 & $\square$ & $\begin{array}{l}\text { Training HCPs to } \\
\text { communicate } \\
\text { sensitive matters } \\
\text { such as SD } \\
\text { Involve different } \\
\text { HCPs such as } \\
\text { clinical nurse } \\
\text { specialists when } \\
\text { discussing the topic } \\
\text { of SD }\end{array}$ \\
\hline $\begin{array}{l}\text { My anxiety and } \\
\text { discomfort about } \\
\text { discussing sexual } \\
\text { problems }\end{array}$ & $17(23)$ & $\begin{array}{c}13 \\
(24.07)\end{array}$ & $4(20)$ & $\begin{array}{l}\text { I am } \\
\text { concerned } \\
\text { that a } \\
\text { discussion on } \\
\text { sexual } \\
\text { problems may } \\
\text { increase } \\
\text { patient's } \\
\text { anxiety and } \\
\text { discomfort }\end{array}$ & $\begin{array}{c}23 \\
(23.4)\end{array}$ & $\begin{array}{c}19 \\
(21.34)\end{array}$ & $4(50)$ & 0.060 & $\square$ & $\begin{array}{l}\text { MS information } \\
\text { leaflets for patients } \\
\text { outlining the } \\
\text { different sexual } \\
\text { problems occurring } \\
\text { in MS } \\
\text { Training HCPs } \\
\text { about } \\
\text { communicating } \\
\text { sensitive matters } \\
\text { such as SD } \\
\text { Training sessions } \\
\text { and observerships } \\
\text { on SD for HCPs } \\
\text { Involve different } \\
\text { HCPs such as } \\
\text { clinical nurse } \\
\text { specialists when } \\
\text { discussing the topic } \\
\text { of SD }\end{array}$ \\
\hline $\begin{array}{l}\text { Presence of other } \\
\text { doctors/ nurses in } \\
\text { the consultation } \\
\text { room }\end{array}$ & $17(23)$ & $\begin{array}{c}13 \\
(24.07)\end{array}$ & $4(20)$ & $\begin{array}{l}\text { Presence of } \\
\text { other } \\
\text { doctors/nurse } \\
\mathrm{s} \text { in the } \\
\text { consultation } \\
\text { room }\end{array}$ & $\begin{array}{c}11 \\
(11.2)\end{array}$ & $\begin{array}{c}9 \\
(10.11)\end{array}$ & $2(25)$ & 0.552 & $\square$ & $\begin{array}{l}\text { Set aside a part of } \\
\text { the consultation } \\
\text { with the patient } \\
\text { alone }\end{array}$ \\
\hline
\end{tabular}




\begin{tabular}{|c|c|c|c|c|c|c|c|c|c|c|}
\hline $\begin{array}{l}\text { Feeling shy or } \\
\text { embarrassed } \\
\text { about talking to } \\
\text { the doctor/nurse }\end{array}$ & 17 (23) & $\begin{array}{c}14 \\
(25.92)\end{array}$ & $3(15)$ & $\begin{array}{l}\text { I feel shy or } \\
\text { embarrassed } \\
\text { to ask }\end{array}$ & $\begin{array}{c}10 \\
(10.2)\end{array}$ & $\begin{array}{c}8 \\
(8.98)\end{array}$ & $2(25)$ & 0.997 & $\square$ & $\begin{array}{l}\text { MS information } \\
\text { leaflets for patients } \\
\text { outlining the } \\
\text { different sexual } \\
\text { problems occurring } \\
\text { in MS and } \\
\text { encouraging } \\
\text { patients to discuss } \\
\text { during clinic visits } \\
\\
\text { Giving permission } \\
\text { to patients to } \\
\text { discuss SD during } \\
\text { clinic visits }\end{array}$ \\
\hline $\begin{array}{l}\text { The doctor/nurse } \\
\text { is of the opposite } \\
\text { gender }\end{array}$ & $\begin{array}{c}16 \\
(21.6)\end{array}$ & $\begin{array}{c}14 \\
(25.92)\end{array}$ & $2(10)$ & $\begin{array}{l}\text { The patient is } \\
\text { of the } \\
\text { opposite } \\
\text { gender }\end{array}$ & $8(8.2)$ & $\begin{array}{c}5 \\
(5.61)\end{array}$ & $3(37.5)$ & 0.431 & $\square$ & $\begin{array}{l}\text { When giving } \\
\text { permission to } \\
\text { patients to discuss } \\
\text { SD during clinic } \\
\text { visits to enquire } \\
\text { about any concerns } \\
\text { from the patient } \\
\text { such as the gender } \\
\text { of the HCP }\end{array}$ \\
\hline $\begin{array}{l}\text { My own attitudes } \\
\text { and beliefs } \\
\text { towards sexual } \\
\text { problems }\end{array}$ & $\begin{array}{c}13 \\
(17.6)\end{array}$ & $\begin{array}{c}10 \\
(18.51)\end{array}$ & $3(15)$ & $\begin{array}{l}\text { My own } \\
\text { attitudes and } \\
\text { beliefs about } \\
\text { sexual } \\
\text { problems }\end{array}$ & $7(7.1)$ & $\begin{array}{c}7 \\
(7.86)\end{array}$ & $0(0)$ & 0.414 & $\square$ & $\begin{array}{l}\text { Training HCPs } \\
\text { about } \\
\text { communicating } \\
\text { sensitive matters } \\
\text { such as SD } \\
\text { Training sessions } \\
\text { and observerships } \\
\text { on SD for HCPs }\end{array}$ \\
\hline $\begin{array}{l}\text { I am currently not } \\
\text { in a relationship }\end{array}$ & $\begin{array}{c}13 \\
(17.6)\end{array}$ & $7(12.96)$ & $6(30)$ & & & & & & $\square$ & $\begin{array}{l}\text { Explaining the } \\
\text { association } \\
\text { between MS and } \\
\text { SD and giving } \\
\text { permission to } \\
\text { patients to discuss } \\
\text { SD during clinic } \\
\text { visits if relevant }\end{array}$ \\
\hline $\begin{array}{l}\text { A discussion on } \\
\text { sexual problems } \\
\text { might reveal } \\
\text { something } \\
\text { embarrassing like } \\
\text { masturbation or } \\
\text { buying Viagra }\end{array}$ & $\begin{array}{c}11 \\
(14.9)\end{array}$ & $8(14.81)$ & $3(15)$ & & & & & & 更 & $\begin{array}{l}\text { MS information } \\
\text { leaflets for patients } \\
\text { outlining the } \\
\text { different sexual } \\
\text { problems occurring } \\
\text { in MS and } \\
\text { encouraging } \\
\text { patients to discuss } \\
\text { during clinic visits } \\
\\
\text { Training HCPs } \\
\text { about } \\
\text { communicating } \\
\text { sensitive matters } \\
\text { such as SD }\end{array}$ \\
\hline $\begin{array}{l}\text { Fear of appearing } \\
\text { to be } \\
\text { inappropriate }\end{array}$ & $\begin{array}{c}10 \\
(13.6)\end{array}$ & $9(16.66)$ & 1 (5) & $\begin{array}{l}\text { Fear of } \\
\text { appearing to } \\
\text { be } \\
\text { inappropriate }\end{array}$ & $\begin{array}{c}17 \\
(17.3)\end{array}$ & $\begin{array}{c}14 \\
(15.73)\end{array}$ & $3(37.5)$ & 0.001 & $\square$ & $\begin{array}{l}\text { MS information } \\
\text { leaflets for patients } \\
\text { outlining the } \\
\text { different sexual } \\
\text { problems occurring } \\
\text { in MS and } \\
\text { encouraging } \\
\text { patients to discuss } \\
\text { during clinic visits } \\
\\
\text { Training HCPs } \\
\text { about } \\
\text { communicating } \\
\text { sensitive matters } \\
\text { such as SD }\end{array}$ \\
\hline
\end{tabular}




\begin{tabular}{|c|c|c|c|c|c|c|c|c|c|c|}
\hline $\begin{array}{l}\text { Fear of offending } \\
\text { the doctor/nurse } \\
\text { by asking }\end{array}$ & $\begin{array}{c}10 \\
(13.5)\end{array}$ & $9(16.66)$ & $1(5)$ & $\begin{array}{l}\text { Fear of } \\
\text { offending the } \\
\text { patient }\end{array}$ & $\begin{array}{c}20 \\
(20.4)\end{array}$ & $\begin{array}{c}18 \\
(20.22)\end{array}$ & $2(25)$ & 0.000 & $\square$ & $\begin{array}{l}\text { MS information } \\
\text { leaflets for patients } \\
\text { outlining the } \\
\text { different sexual } \\
\text { problems occurring } \\
\text { in MS and } \\
\text { encouraging } \\
\text { patients to discuss } \\
\text { during clinic visits } \\
\text { Training HCPs } \\
\text { about } \\
\text { communicating } \\
\text { sensitive matters } \\
\text { such as SD }\end{array}$ \\
\hline $\begin{array}{l}\text { Age gap between } \\
\text { the doctor/nurse } \\
\text { and myself }\end{array}$ & $7(9.5)$ & $6(11.11)$ & 1 (5) & $\begin{array}{l}\text { Age gap } \\
\text { between the } \\
\text { patient and } \\
\text { myself }\end{array}$ & $5(5.1)$ & $\begin{array}{c}3 \\
(3.37)\end{array}$ & $2(25)$ & 0.000 & $\square$ & $\begin{array}{l}\text { When giving } \\
\text { permission to } \\
\text { patients to discuss } \\
\text { SD during clinic } \\
\text { visits to enquire } \\
\text { about any concerns } \\
\text { from the patient } \\
\text { such as the age gap } \\
\text { with the HCP }\end{array}$ \\
\hline $\begin{array}{l}\text { A discussion on } \\
\text { sexual problems } \\
\text { interferes with my } \\
\text { privacy }\end{array}$ & $7(9.5)$ & $4(7.4)$ & $3(15)$ & & & & & & $\square$ & $\begin{array}{l}\text { MS information } \\
\text { leaflets for patients } \\
\text { outlining the } \\
\text { different sexual } \\
\text { problems occurring } \\
\text { in MS and } \\
\text { encouraging } \\
\text { patients to discuss } \\
\text { during clinic visits } \\
\text { Training HCPs } \\
\text { about } \\
\text { communicating } \\
\text { sensitive matters } \\
\text { such as SD }\end{array}$ \\
\hline $\begin{array}{l}\text { I do not see sexual } \\
\text { dysfunction as } \\
\text { being an MS- } \\
\text { related problem }\end{array}$ & $6(8.1)$ & $5(9.25)$ & $1(5)$ & $\begin{array}{l}\text { I do not see } \\
\text { sexual } \\
\text { dysfunction } \\
\text { as being an } \\
\text { MS-related } \\
\text { problem }\end{array}$ & 0 & $0(0)$ & $0(0)$ & 0.000 & $\square$ & $\begin{array}{l}\text { Explaining the } \\
\text { association } \\
\text { between MS and } \\
\text { SD and giving } \\
\text { permission to } \\
\text { patients to discuss } \\
\text { SD during clinic } \\
\text { visits }\end{array}$ \\
\hline Language barriers & $3(4.1)$ & $3(5.55)$ & $0(0)$ & $\begin{array}{l}\text { Language } \\
\text { barriers }\end{array}$ & $8(8.2)$ & $\begin{array}{c}7 \\
(7.86)\end{array}$ & $1(12.5)$ & 0.589 & $\square$ & $\begin{array}{l}\text { When giving } \\
\text { permission to } \\
\text { patients to discuss } \\
\text { SD during clinic } \\
\text { visits to enquire } \\
\text { about any concerns } \\
\text { from the patient } \\
\text { such as the } \\
\text { language barrier } \\
\text { with the HCP }\end{array}$ \\
\hline
\end{tabular}




\begin{tabular}{|c|c|c|c|c|c|c|c|c|c|c|}
\hline $\begin{array}{l}\text { Religious or } \\
\text { cultural factors }\end{array}$ & $2(2.7)$ & $2(3.7)$ & $0(0)$ & $\begin{array}{l}\text { My own } \\
\text { religious or } \\
\text { cultural } \\
\text { factors }\end{array}$ & $2(2)$ & $\begin{array}{c}2 \\
(2.24)\end{array}$ & $0(0)$ & 0.218 & $\square$ & $\begin{array}{l}\text { MS information } \\
\text { leaflets for patients } \\
\text { outlining the } \\
\text { different sexual } \\
\text { problems occurring } \\
\text { in MS and } \\
\text { encouraging } \\
\text { patients to discuss } \\
\text { during clinic visits } \\
\text { Training HCPs } \\
\text { about } \\
\text { communicating } \\
\text { sensitive matters } \\
\text { such as SD } \\
\text { When giving } \\
\text { permission to } \\
\text { patients to discuss } \\
\text { SD during clinic } \\
\text { visits to enquire } \\
\text { about any concerns } \\
\text { from the patient } \\
\text { such as religion or } \\
\text { culture }\end{array}$ \\
\hline & & & & $\begin{array}{l}\text { I do not feel } \\
\text { that the } \\
\text { patient is } \\
\text { ready to } \\
\text { discuss the } \\
\text { problem }\end{array}$ & $\begin{array}{c}27 \\
(27.6)\end{array}$ & $\begin{array}{c}24 \\
(26.96)\end{array}$ & $3(37.5)$ & & $\square$ & $\begin{array}{l}\text { MS information } \\
\text { leaflets for patients } \\
\text { outlining the } \\
\text { different sexual } \\
\text { problems occurring } \\
\text { in MS and } \\
\text { encouraging } \\
\text { patients to discuss } \\
\text { during clinic visits }\end{array}$ \\
\hline & & & & $\begin{array}{l}\text { I think this is } \\
\text { not } \\
\text { something I } \\
\text { should adress } \\
\text { (it's someone } \\
\text { else's job) }\end{array}$ & $4(4.1)$ & $\begin{array}{c}4 \\
(4.49)\end{array}$ & $0(0)$ & & $\square$ & $\begin{array}{l}\text { Training HCPs } \\
\text { about } \\
\text { communicating } \\
\text { sensitive matters } \\
\text { such as SD }\end{array}$ \\
\hline & & & & $\begin{array}{l}\text { Lack of } \\
\text { knowledge in } \\
\text { this field }\end{array}$ & $\begin{array}{c}30 \\
(30.6)\end{array}$ & $\begin{array}{c}28 \\
(31.46)\end{array}$ & $2(25)$ & & 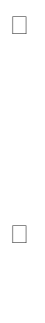 & $\begin{array}{l}\text { Training HCPs } \\
\text { about } \\
\text { communicating } \\
\text { sensitive matters } \\
\text { such as SD } \\
\text { Training sessions } \\
\text { and observerships } \\
\text { on SD for HCPs }\end{array}$ \\
\hline & & & & $\begin{array}{l}\text { I was not } \\
\text { trained to } \\
\text { discuss sexual } \\
\text { problems }\end{array}$ & $\begin{array}{c}19 \\
(19.4)\end{array}$ & $\begin{array}{c}18 \\
(20.22)\end{array}$ & $1(12.5)$ & & 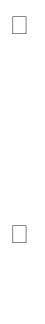 & $\begin{array}{l}\text { Training HCPs } \\
\text { about } \\
\text { communicating } \\
\text { sensitive matters } \\
\text { such as SD } \\
\text { Training sessions } \\
\text { and observerships } \\
\text { on SD for HCPs }\end{array}$ \\
\hline & & & & $\begin{array}{l}\text { Elderly age of } \\
\text { the patient }\end{array}$ & $\begin{array}{c}14 \\
(14.3)\end{array}$ & $\begin{array}{c}12 \\
(13.48)\end{array}$ & $2(25)$ & & 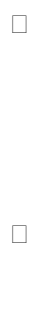 & $\begin{array}{l}\text { Training HCPs } \\
\text { about } \\
\text { communicating } \\
\text { sensitive matters } \\
\text { such as SD } \\
\text { Training sessions } \\
\text { and observerships } \\
\text { on SD for HCPs }\end{array}$ \\
\hline
\end{tabular}


MS : multiple sclerosis, HCPs: healthcare professionals, SD: sexual dysfunction, PLISSIT:

permission, limited information, specific suggestions, intensive therapy 